\title{
Religion and culture: Revisiting a close relative
}

\begin{tabular}{|c|c|}
\hline \multicolumn{2}{|c|}{$\begin{array}{l}\text { Author: } \\
\text { Jaco Beyers }{ }^{1,2} \text { (]) }\end{array}$} \\
\hline \multicolumn{2}{|c|}{ 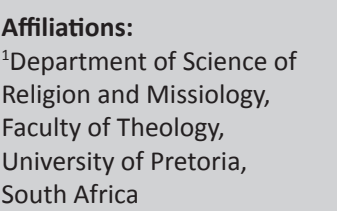 } \\
\hline \multicolumn{2}{|c|}{$\begin{array}{l}{ }^{2} \text { Department of Biblical and } \\
\text { Religious Studies, Faculty of } \\
\text { Theology, University of } \\
\text { Pretoria, South Africa }\end{array}$} \\
\hline \multicolumn{2}{|c|}{$\begin{array}{l}\text { Research Project Registration: } \\
\text { Project Leader: J. Beyers } \\
\text { Project Number: } 02440237\end{array}$} \\
\hline \multicolumn{2}{|c|}{$\begin{array}{l}\text { Description: } \\
\text { This research is part of the } \\
\text { project, 'Religion and } \\
\text { Culture', directed by Prof. } \\
\text { Dr Jaco Beyers, Departmen } \\
\text { Science of Religion and } \\
\text { Missiology, Faculty of } \\
\text { Theology, University of } \\
\text { Pretoria. }\end{array}$} \\
\hline \multicolumn{2}{|c|}{$\begin{array}{l}\text { Corresponding author: } \\
\text { Jaco Beyers, } \\
\text { jaco.beyers@up.ac.za }\end{array}$} \\
\hline \multicolumn{2}{|c|}{$\begin{array}{l}\text { Received: } 29 \text { Aug. } 2016 \\
\text { Accepted: } 23 \text { Nov. } 2016 \\
\text { Published: } 28 \text { July } 2017\end{array}$} \\
\hline \multicolumn{2}{|c|}{$\begin{array}{l}\text { How to cite this article: } \\
\text { Beyers, J., 2017, Religion and } \\
\text { culture: Revisiting a close } \\
\text { relative', HTS Teologiese } \\
\text { Studies/Theological Studies } \\
\text { 73(1), a3864. https://doi. } \\
\text { org/10.4102/hts.v73i1.3864 }\end{array}$} \\
\hline \multicolumn{2}{|c|}{$\begin{array}{l}\text { Copyright: } \\
\text { (c) 2017. The Authors. } \\
\text { Licensee: AOSIS. This w } \\
\text { is licensed under the } \\
\text { Creative Commons } \\
\text { Attribution License. }\end{array}$} \\
\hline \multicolumn{2}{|l|}{ Read online: } \\
\hline 回神回 & $\begin{array}{l}\text { Scan this QR } \\
\text { code with your } \\
\text { smart phone or } \\
\text { mobile device } \\
\text { to read online. }\end{array}$ \\
\hline
\end{tabular}

Religion and culture always exist in a close relation. Together with aesthetics and ethics, religion constitutes culture. As ethnicity becomes part of the related concepts, the relation with religion needs explanation. This article wants to emphasise that when studying religion, a study of culture is necessary. This statement is argued from three positions: (1) cultural migrations occurring worldwide, (2) religion as cultural identity marker causing the borders between culture and religion to blur and (3) the location of religion within culture causing religion to act as custodian of culture. This results in a situation where any signs of animosity towards culture are interpreted as opposition towards religion. All three arguments necessitate studying ethnicity when studying religion.

\section{Introduction}

When discussing terms and processes in the study of religions, culture and religion constantly appear as important concepts. My argument is that the study of religions requires studying ethnicity and culture. This statement is framed within the South African post-colonial and postApartheid context. To formulate the issue at hand, a more appropriate question might be helpful: What are the implications of the relatedness of religion, ethnicity and culture for the process of reconciliation in a post-colonial and post-Apartheid South Africa? If this is our focus, we must recognise the relevance and meaning of related concepts. Culture, religion, anthropology, ethnography and reconciliation become central issues related to the conversation.

My arguments supporting the relevance of ethnicity and culture in studying religion will be built around three main points: Cultural migrations; religion as cultural identity marker; and the location of religion within culture. It will, however, be important to first of all discuss the ways in which religion, ethnicity and culture relate. After this brief discussion, the three arguments will be set and then the implications for reconciliation between cultures and religions in South Africa will be discussed.

\section{What exactly is the problem?}

If religion is a cultural tradition, is it possible to separate religion and culture? Can you belong to the Western culture and still practice Muslim religion (cf. Ramadan's [2004] inquiry)? To this question must be added, can you be a white Christian in Africa without being labelled a colonist and oppressor? Can you be African without being labelled as primitive and prone to animism and magic? Has religion become a cultural identity marker in a South African context, demarcating the borders between people? Belonging to a particular religion implies belonging to a particular culture. From this position follows a crude generalisation that to belong to a particular culture implies belonging to a particular religion. It is clear that religion and culture cannot be separated. Ramadan (2010:214), however, maintains that Islam, for one, must not be viewed as a culture. The essence of Islam is religious (Ramadan 2010:214). Many adherents of different religions will agree to this when applied to their own religious convictions. However, it cannot be denied that religion is a cultural expression (Boyer 2001:47). In this regard, culture and religion must be viewed as relatives. This has implications on how to study religion. If religion is seen as a segment of culture, studying religion becomes an anthropological and ethnographic exercise.

The relation between culture and religion is an old and still on-going debate. Ever since Aristotle used the term ethnos to identify the groups of people living outside of the Greek polis, indicating them as primitive, people belonging to different cultures and religions could be labelled as 'outsiders, uncultured and irreligious' (MacKay 2000:98). During the Enlightenment period, Europeans took over this notion of Aristotle to label all non-Europeans as 'uncivilised' (MacKay 2000:98). The Enlightenment implication that all reality can be classified resulted in nations and people being hierarchically categorised. This classification was based on perceived natural mental,

Note: This article was presented at the meeting of the Association for the Study of Religions in Southern Africa (ASRSA), which formed part of the Third Joint Conference of Academic Societies in the field of Religion and Theology, 11-15 July 2016 at the University of Pretoria. 
physical and spiritual abilities. The result was according to MacKay (2000:98) that 'group identity was essentially defined in terms of race'. David Chidester $(1996: 36,41)$ alludes to this when he describes the European attitude towards the natural inhabitants encountered at the Cape Colony during the 16th and 17th century as being 'less than human'. This remained the dominant discourse between cultures and different religions in South Africa, culminating in the Apartheid laws.

In a post-colonial, post-Apartheid South Africa, a reconfiguration of social structures is taking place. The hierarchical structure of Enlightenment arrangements of cultures, races and religions needs to be reconsidered. This reconfiguration includes the consideration of how cultures, races and people with different religious affiliations relate to one another. This process may be labelled reconciliation, but in fact refers to a process of seeking identity. A survey of the religious landscape of South Africa should include taking cognisance of the immanent racial and cultural relations. Only then, a responsible reconfiguration (or reconciliation) of relations between races, religions and cultures is possible.

\section{Interrelated concepts}

In the cauldron from which we serve up our conversation are a great variety of concepts, some spicy and unfamiliar, some familiar and not as interesting, nevertheless all contributing to understanding and explaining the way in which religion can be studied.

\section{Culture and religion}

In our discussion on the relatedness of culture to religion, we should state it clearly that the approach in this conversation is not emphasising cultural materialism, although it must be recognised that cultural materialism might at some stage in the discussion play a role. My focus is much more concerned with an understanding of culture in terms of sociocultural systems.

Studying religion is an ambiguous task. With some uncertainty as to what exactly constitutes religion (cf. Braun 2000:4; Schilderman 2014:176), there may be uncertainty as to what ought to be studied and how to study it. What is clear is where to search for forms of religion. Mulder (1985:35) indicates that studying religion implies religion as an expression of human culture. Religion is, thus, expressed and clothed in cultural guise. Comprehending religion then implies studying human culture. The reciprocal interaction between culture and religion must be recognised: religion is determined by culture, but religion also influences culture. The fate of religion and culture is, thus, interwoven.

The definition of what religion is, however, still remains outstanding. The problem with defining religion is according to Braun (2000:4) that there are too many meanings and the meanings are too indeterminate to be of value. The purpose of this conversation is however not to attempt a discussion on the problem of defining religion. James Cox (2010:3-7) provides direction on this matter by suggesting that studying the groups of definitions has more value than studying the definitions themselves. For the sake of this study, a sociological understanding as to what constitutes religion is followed.

When religion is studied as being part of the Cultural Sciences (cf. Figl 2003:36), requiring an anthropological approach, ${ }^{1}$ where culture refers to the totality of human existence in the world ${ }^{2}$ it can easily happen that the concept of religion is absorbed in the concept of culture. Rosalind Hackett (2005:144) confirms the difficulty of indicating boundaries between religion and culture because of the fact that religion and anthropology share in many social and cultural theories.

The opposite relation between culture and religion is also possible: religion in opposition to culture (religion as anticulture). Even when religion is part of culture, it is possible to differentiate religion from a worldview governing a cultural community. The conclusion Johann Figl (2003:36) comes to is that whatever the relation between culture and religion is, either absorbed or in opposition, it still remains identifiable what constitutes religion. There are many elements considered part of religion which are connected to cultural elements (i.e. politics, science, art and literature). Figl (2003:36) suggests that a Western understanding of religion is especially prone to understand religion as determined by culture. In the end, the intertwined relation of religion and culture cannot be denied or ignored (Figl 2003:37).

The debate on what constitutes culture is still a lively debate because of the 'multiplicity of its referents' as well as the 'studied vagueness' (Geertz 1973:89). There are, however, not a shortage of definitions as to what constitutes culture: From Max Weber's theorem that humans are animals suspended in webs of significance that they have spun themselves to E.B. Tylor's vague description of culture as 'most complex whole' to Kluckhohn's elaborate twenty-seven page long definition or Goodenough's inclusion of 'heart and mind' as the location of culture (Geertz 1973:4, 5, 11). The main elements as to what culture is must be understood as the result of a long line of research culminating in a wide variety of perspectives.

\section{Clifford Geertz (1973) defines culture as follows:}

Culture denotes a historically transmitted pattern of meanings embodied in symbols, a system of inherited conceptions expressed in symbolic forms by means of which men communicate, perpetuate, and develop their knowledge about and attitudes toward life. (p. 89)

For Geertz (1973:5), culture indeed reflects the webs Weber referred to. Studying culture, however, does not only intend description of these webs but also much rather intends a search for meaning.

1.The difference between anthropology and ethnography is summarised by Hacket (2005-144): Anthropology refers to the generalised, theoretical reflection, whereas (2005:144): Anthop to the empirical fieldwork on a particular culture incorporating ins

2.Culture is then understood in the widest ethnographic sense to refer to knowledge beliefs, art, ethics, customs, practices and skills, which humans as members of beliefs, art, ethics, customs, practices and skills, which humans as members of a
community have acquired (based on the definition of culture by E.B. Tylor quoted in Figl 2003:36). 
Anthropology as the attempt at studying culture and religion requires a definition of what constitutes religion. As to his definition of religion, Geertz (1973) says:

religion is a system of symbols which acts to establish powerful, pervasive and long-lasting moods and motivations in men by formulating conceptions of a general order of existence and clothing the conceptions with such an aura of factuality that the moods and motivation seem uniquely realistic. (p. 90)

As to the interrelatedness of culture and religion, Geertz (1973) emphasises:

The importance of religion lies in its capacity to serve for the individual or for a group, as a source of general, yet distinctive, conceptions of the world, the self and the relations between them ... (p. 123)

Religion, thus, possesses an orientating function, providing society with criteria to find its place (identity) within the world.

Parsons' theory on culture consists of different elements as Parsons modified and elaborated on his theory on culture over time. Three phases of development of the concept of culture by Parsons are identified by Munch and Smelser (1992):

- Phase 1: Culture did not apparently play a role in Parsons' theory of the structure of social action (Munch \& Smelser 1992:89).

- Phase 2: Action-theoretical definition: Culture is part of a comprehensive 'action system'. Two subsystems of the general action system can be identified: The Personal and Social systems. Later, a third subsystem was added, namely the 'behavioural system'. Even later a fourth subsystem was added: 'the cultural subsystem', a system consisting of abstract and symbolically mediated entities (Munch \& Smelser 1992:93).

- Phase 3: Parsons enriched his theory of culture by adding the perspective that the culture-constitutive set of standards is understood as code in correlation with Chomsky's theory of generative grammar (Munch \& Smelser 1992:94). Parsons (1977) defines culture as:

Culture is understood as an ordered symbolic system that is, a symbolically mediated pattern of values or standards of appropriateness that permits the construction of a set of action-guiding, normative, conventional rules through which significant cultural objects are generated and used. (p. 168)

Munch evaluates Parsons' theory on culture in an antireductionist way. For Munch and Smelser (1992:111), Parsons' utilitarian theory of action is only one theory part of a larger more comprehensive theoretical model. There are, thus, more views to consider than only the utilitarian. When comparing the definitions of culture as provided by Geertz and Parsons, Peacock (1981:123) comments on the similarities. Both Parsons and Geertz agree that society is subordinate to culture. Both follow Max Weber's suggestion of action theory.
It is, however, clear to me that both Parsons and Geertz approach religion from a functionalist position. Religion has a function within society (along the line of argumentation of Durkheim) to provide society with guidelines as to find identity. The emphasis in studying religion is to focus on the actions that what is done. Parsons and Geertz follow in a long line of scholars considering what constitutes culture. Both Parsons and Geertz follow Weber in discerning the relation of action and meaning. Human behaviour and activity (action) including religion as human activity - must be interpreted to gain meaning from such activity. It is important to note that behaviour with meaning constitutes culture. Meaning is contextually assigned, and therefore, similar behaviour among different communities only differs in terms of the meaning assigned to such behaviour. Different ethnic groups will have different criteria by which meaning is determined.

Lourens Minnema (2014:3) identifies three stages of development in the understanding of culture:

- Stage 1: Culture is a pre-given constant. Culture is seen as an all-encompassing reality, as a way of life of a people. Cultural patterns are pre-given. People belonging to a culture are only bearers of that culture. Culture is characterised by custom and habitual behaviour. This type of culture is typical of traditional cultures of small and non-complex societies.

- Stage 2: Culture is a dominating power and a source of conflict and innovation. During the 1960s, culture became a source of conflict and a space for innovative initiatives. Cultural patterns are challenged as they become subversive. Alternative cultures are perceived as being innovative. People belonging to this type of culture are producers of culture as well as sub-cultures. An example of this type of culture is the modern Western society since the Renaissance.

- Stage 3: Culture is a domain of potentiality and choice. The way in which culture is interpreted today is that culture is perceived as providing room for freedom of choice and combinations of elements. Cultural patterns are marketable and transferable, and their power is negotiable. People belonging to this type of culture are mainly seen as consumers of culture although also as producers. They produce something new by way of combination and present it as commodity ready for consumption. Exponents of this type of culture are multicultural societies or mixed cultures or postmodern cultures subject to globalisation.

From this analysis, the constant production and consumption of culture are emphasised. When religion forms a segment of culture under the third stage described by Minnema, religion becomes a commodity prepared for utility and consumption. A problem, however, arises when people with a Stage 1 or 2 understanding of culture encounter a community where a Stage 3 understanding of culture is prevalent. If culture is perceived as a given, there can be no negotiation as to integration or accommodation. The different stages of cultural development must be taken into account when studying inter-cultural contact. 


\section{Ethnicity and religion}

The relation between ethnicity and religion has been viewed differently over centuries. MacKay (2000) suggests two existing models of viewing the relationship. During the 19th century, the Primordialist view governed relations between religion and ethnicity. This changed to a Circumstantialist position during the late 20th century. MacKay (2000:104) suggests a third possible position for current times, that of Constructivism, combining the two preceding models.

The Primordialist theory (MacKay 2000:100) was the reigning theory during the 19th century, maintaining that ethnicity is a priori given and not determined by circumstances. This also applies to religion. Religion is regarded as a priori given as part of identity of an ethnic group. This reflects Minnema's identification of Stage 1 of cultural development. There exists congruence between religion and ethnic identity. The core element determining identity in this case is religion.

The Circumstantialist theory (MacKay 2000:102) holds that the ethnic identity is determined by circumstances. As circumstances change so does identity. Social interactions determine group identity. The result is that identity is not perceived as fixed. The borders between ethnic groups are part of a dynamic process and not fixed. Religion is seen as part of a social system. The borders of religious and ethnic identity do not necessarily overlap. In communities where the relation between ethnicity and religion is viewed in this way, integration is much more likely to succeed.

MacKay (2000:104), however, suggests a third possibility with Constructivism. This model combines the Primordialist and Circumstantialist position. Constructivism recognises that ethnic identity is formed in part by birth and not by choice. This identity might be re-enforced by mythic traditions emphasising the uniqueness of a particular community. The Constructivistic position, however, also recognises that these (given) elements determining identity are also constantly but gradually reconstructed based on an interpretation of the context, emphasising the circumstantial influence on identity formation. Identity is then constantly under revision based on interaction and exposure to other group identities. Ethnic identity then becomes flexible.

To understand group identity, the circumstances of ethnic groups may then be studied to determine which circumstantial elements can contribute to formation of identity. According to Frederik Barth (1969:15-16), studying the boundaries between ethnic groups may, however, prove to be more revealing. It is the ethnic boundary that defines a group and not the cultural content it encloses (Barth 1969:15). It is especially at the boundaries that the identity stands out sharper. Studying ethnic communities at the boundaries of identity will highlight the decisions made in reaction to circumstantial elements determining identity. For example, how ethnic groups make a decision on what clothes to wear or music to listen to will be based on ethical convictions that differ from another ethnic community. These ethical convictions function at the border between ethnic groups. There may be ethics that two groups may agree on. These convictions would rather stand at the centre of each group than at the periphery of identity. Studying the boundaries may prove important in understanding ethnic differences, and it may contribute to reconciling differences.

\section{Why is it necessary to study ethnicity and culture when studying religion?}

Can one study religion without studying ethnicity and culture? One can only understand the nature of religion when one understands its connectedness to ethnicity and culture. The interrelatedness and interaction of people from different cultures and races belonging to different religions are our focus here. This endeavour becomes even more urgent when considering current world events. Globalisation, post-colonialism and growing multi-cultural societies (because of migration nationally or internationally because of economic, social, political and health reasons) necessitate an understanding of the relatedness of culture, ethnicity and religion.

My argument here is that studying religion requires more emphasis on a study of culture and ethnicity. The goal is to suggest and argue the importance of studying culture and ethnicity to understand religious diversity especially in South Africa. Understanding ethnicity can contribute to enhanced inter-religious dialogue and provide possible guidelines as to inter-cultural reconciliation in South Africa.

Now that the interrelatedness of the concepts has been discussed, I now want to present three arguments why studying ethnicity and culture has become important in understanding religion. The three arguments are: Cultural migrations necessitate the studying of cultures; religion as cultural identity marker must be considered and the relocating of religion to culture needs to be taken into account.

\section{Cultural migrations necessitate study of cultures when studying religions}

There is currently a need for attention to anthropology of religion. This need is identified by Hackett (2005:144) as the result of three reasons: (1) The changing nature and location of people as manifested in mass migrations and mass conversion to different religions. In a post-Apartheid South African context a 'migration' took place. People encounter one another now in a different context, no longer oppressed and oppressor, but in new circumstances as equals. The reconfiguration of relations between races, cultures and religions requires a need for anthropology of religion. (2) Scholars studying religion work more interdisciplinary and (3) new insights have come to the fore because of perspectives from post-colonialism, poststructuralism and postmodernism. To this list, I want to add 
globalisation and the growing multi-cultural communities. Changing paradigms cause reconfigurations in society, requiring new methods of studying society. Each case of religion must be studied within its own context in relation to other religions practiced among other racial groups. No universal theory of inter-cultural and inter-religious relations can be applied to every context. Each context must be studied on its own. This is confirmed by Scott and Hirschkind (2006):

The various traditions that anthropologists call religions cannot be understood as cultural elaborations of a universal form of experience, a sui generis category of human knowledge, but must be analysed in their particularity, as the products of specific practices of disciplines, authority and power. (pp. 6-7)

Tariq Ramadan (2004:200) in discussing the possibility of inter-religious dialogue also refers to the importance of culture. In the interactions between religions, Ramadan (2010:5) suggests that the principle of integration plays a dominant role. When cultures interact, there is no place for isolation, withdrawal and 'obsession with identity'. Rather entering into authentic dialogue as equals is necessary which will eventually lead to mutual enrichment and 'partners in action'. In the end, the interaction between religions is not about relativising one's own convictions and seeking universal neutral principles, it is rather about acceptance and respect of pluralism, diversity and the belief of the Other (Ramadan 2010:6).

How then to study religion when the borders of religion and other identifying elements overlap? For example, if religion, culture and ethnicity cannot be separated, does it influence the way in which religion is studied? There seem to be three scenarios to this problem (cf. MacKay 2000:96-97):

1. The ethnicity of a group is explained in terms of their religious beliefs. An example would be Jewish ethnicity as it is the result of practicing Judaism. Religion is the primary element in Jewish identity.

2. Religion is explained as the result of ethnicity. Muslim belief is the result of Arab ethnicity. The group's ethnic identity is the primary element in determining identity.

3. More elements than religion and ethnicity are at play determining group identity. Elements such as language, geography, values, worldview and a shared history come to mind.

In this construct of relatedness between religion and ethnicity, religion must be studied from an anthropological approach. Religion becomes one expression of human identity among many other different expressions of identity.

Religion either embraces or denies culture (cf. Figl 2003:35). As culture is associated with ethnicity, religion can easily be embraced by an ethnic group. Ramadan (2010:214) suggests the principle of integration as way of making religion at home within a cultural context. The result would be to distinguish between (Islamic) 'religion' and (Islamic) 'civilisation' (Ramadan 2010:214). The core of a religion is clothed in the forms of the various cultures in whose midst a religion exists (Ramadan 2010:215). Religion is expressed in cultural terms. So when an individual belonging to a particular religion comes from a specific cultural background and ends up in a different cultural environment, the individual integrates the religious convictions into the new cultural context, as there should be a clear difference between the religion and the culture of origin (Ramadan 2010:215).

Identity should be determined by multiple factors to which one remains open to. This, however, does not mean accepting everything of the culture. A critical evaluation of values is necessary. Together with being critical, Ramadan (2010:219) suggests a good dose of creativity to integrate in a responsible way.

The problem, however, arises when people with a particular religious affiliation coming from a particular culture enter a different culture where people have a different religious affiliation. Based on Lincoln's understanding of cultural encounter (1989:6-7), struggle between cultures may ensue. On a continuum, reactions towards the other may vary from 'polite disinterest', demarcation, conflict to outright war. Because of conflict of interest and added to that a stereotyped perception of the other culture, permanent animosity might result from that. The question would be how to have nations, religions and cultures co-exist peacefully, while maintaining their own unique identity.

Because of globalisation, religions all over the world rarely exist in isolation. Religions are constantly exposed to a multireligious environment. In this plurality, each religion is in need of maintaining its unique identity. Studying religions will need to take into consideration not only the culture from which a religion originates but also the cultural network a religion ends up in because of globalisation and migration. Creating harmony between religious communities living in close proximity needs to take cultural and ethnic considerations into account.

\section{Religion as cultural identity marker}

Linda Woodhead (2011:112, 119) differentiates between religion as belief and religion as identity marker. Religion as belief refers to a religious interest in dogmas, doctrines and propositions. Religion as identity marker refers to religion as a source of identity, either socially or as personal choice. Based on Woodhead's differentiation, Kilp (2011:212) indicates how religion has currently excelled at being a cultural identity marker, increasingly so in Europe. As so many different factors are at play in determining identity, cultural identity must, however, be seen as in flux (Vroom 1996:118). The result is that people become alienated from the traditional religious beliefs and practices and turn to culturalreligious identities, which do not necessarily include religious beliefs. At play here are the elements already identified: assigned meaning of behaviour; culture as utility; three stages of cultural development. These factors must be kept in mind when a cultural identity is created. 
It is also important to note that cultural identity is ideologically motivated. People profess something about their culture to motivate the manifestation of a particular group (Vroom 1996:118). This cultural religious identity provides people with a feeling of certainty, order and meaning - a general feeling of belonging. This may serve as explanation to the struggle for power in multi-cultural societies, confirming Lincoln's (1989:6-7) theory of 'hegemonic struggle'. It is clear from this that struggle as well as attempts at reconciliation between cultures should be seen as efforts at establishing identity. Understanding the effort of creating identity requires an understanding of how people perceive the interplay of religion and ethnicity in creating identity. Religious affiliation does not need to overlap with aspects of ethnic identity. This reflects Minnema's Stages 2 and 3 of cultural development.

The Primordialist theory implies that one belonging to a specific religion can become part of a cultural group and still retain a religious identity. The result, however, may be that one will not be culturally equal to the cultural group into which one enters (Kilp 2011:202). We see the same situation with recent immigrants from Syria and Pakistan to Germany. Immigrants are welcomed into the German culture although they have a different religious affiliation. But still many Germans do not recognise the immigrants as equal members of society. To be part of the German people one has to subscribe to all that it means to be a German: language, clothing, religion and so on. Immigrants tend to become second-class citizens. Immigrants are still being identified in terms of their religious affiliation. Religion is still their main identity marker and not the new culture they are trying to adapt to. This sentiment is also witnessed in the discourse on immigration policies in the United States.

Based on religious grounds, differences are viewed from a value perspective. Differences are now viewed either as good or bad. The differences in relation to the own identity are perceived to be based on being different, being 'bad' (Kilp 2011:203). The ethical evaluation of the other increases in content and is perceived as a growing threat requiring protection of the self, which is now polarised as being good as opposed to the other which is now perceived as bad. Kilp (2011:204) illustrates that the other is necessary to maintain the identity of the self. The other as evil is necessary to legitimise the self as good, pure and correct. The absence of the other (the cultural enemy) is dysfunctional.

Cultural identity is, however, not fixed but dynamic (Vroom 1996:118). Cultural identity can change over time. Cultural identity is an ideological interpretation as to how people view themselves and want to be viewed by others. People present their identity and thus communicate something about their culture. Cultural identity is, thus, constructed (Vroom 1996:118). The question would arise: in what does identity then lie? If identity is created, what criteria do people select to construct their identity? Cultural groups may make selections of events or elements in history to constitute their identity (Vroom 1996:119).
A problem arises when multiple cultures co-exist in close proximity and even more so in the same country. What and who determines cultural identity then? One can maintain one's cultural identity and still belong to a particular nation sharing another culture. It is then possible to belong to several cultures simultaneously. Interestingly, Vroom (1996:121) sees cultural exchange as more normal than maintaining cultural identity.

In the struggle to adapt and take refuge in a different culture, conflict might arise. Goodenough (1957:167) defines culture as a process: 'A society's culture consists of whatever it is one has to know or believe in order to operate in a manner acceptable to its members'. Based on this definition, a strict exclusion is imprinted. One is only accepted when one knows, believes and acts in a familiar way to community. Part of the knowledge, convictions and actions is acceptance of a structure of meaning reached on consensus by a community (Geertz 1973:12). Meaning is negotiated through aesthetics.

It seems harmony between religious groups living in close proximity can only be reached when conformity from both sides is employed. Meeting one another at the borders of cultural identity and negotiating boundary markers can lead to a positive conformity. Conformity does not include taking on the characteristics of another culture, but merely recognising differences at the borders and respecting them.

\section{Religion relocated to culture}

Matt Waggoner (2011:219) argues that religion has indeed relocated. The shift has taken place that religion no longer resides in the consciousness but within culture. Waggoner's argument in short is that a shift has taken place. Religion is no longer perceived to be subjectively imagined, locating religion in the bodies and brains of people participating in religion, but rather religion is located in culture or a social system. The implication is that studying religion requires a change in focus, away from the individual and group consciousness and finding the location of religion in the exterior to the subjective.

This argument by Waggoner goes back to Bruce Lincoln's (1989) contribution to the debate on religion and culture. Lincoln managed to combine Durkheim and Marx's orientation to the study of religion. The first step is to acknowledge that societies construct religion. Secondly, religion, as culture, is always associated with a struggle for power. Culture, especially religion, becomes a site where power and privileges in society are negotiated. Lincoln $(1989: 6,174)$ refers to this as the 'hegemonic struggle'. Culture has an ideological role in this hegemonic struggle. Culture ignores its historical origin and makes transcendental claims to authorise its own position of power and discredit other claims. Further, the origin of religion is from the point of religion always an authoritative transcendent or suprahistorical source, thereby concealing the cultural and historical origins. 
Lincoln (2000:416), however, refrains from naming religion as a 'core component' of culture. Aesthetics and ethics are core components of culture as they are concerns for all human cultures. Kierkegaard (in Pattison 2004:4) seems to have added the element of religion to the two components constituting culture: aesthetics and ethics. The role of religion in culture, however, changes from one context to the other. Religion, however, does play a 'role of prime importance' in culture (Lincoln 2000:416) although this role is inconsistent. The argument by Lincoln makes provision for a situation, as Lincoln points out, how religion as one of the essential elements in culture can from time to time dominate that which is considered as culture (Lincoln 2000:420).

The implication Waggoner (2011:219) draws from Lincoln's analysis is to point out that religion is in fact a subset of culture and not something sui generis. It is clear that religion participates in the hegemonic struggle in culture. Religion can then act as cultural identity marker. There are, however, many potential cultural markers (i.e. language, shared history, race and geography). People can view others not in terms of ethnicity but primarily in terms of religion. Ethnicity and religion overlap causing cultural or religious animosity to spill over to religious or cultural animosity.

This article does not pretend to have the solution to these cases of animosity. This article wants to argue that it is important in the study of religion to study ethnicity and culture as well.

\section{What are the implications?}

If the argument is that to study religion a clear cognisance of culture and ethnicity is necessary, what are the implications? There are two implications mentioned here: In the light of the above arguments, studying religion requires a new methodology and a new attitude towards reconciliation, namely making peace with diversity and adversity.

\section{Methodology}

When studying religion, a multi-disciplinary approach will be necessary. This is, however, not new. What is new is that the emphasis will have to change. Much more attention should be paid to an anthropological approach where cultural and ethnic studies are considered as part of studying religion. Also this is not new. What I suggest is that the anthropological approach should be focussed on studying the boundaries between cultures, which is in line with Frederik Barth's (1969) suggestion. Studying the boundaries between cultures helps to identify those elements that constitute cultural identity, whether they are ethics, religion or aesthetics or a combination of some sort.

In some cases, cultures might meet where the Primordialist understanding of ethnicity determines a cultural group's understanding of its identity. Then, it is most unlikely that there will be change as to how such a group understands its own identity. Where a group with a Circumstantialist understanding of ethnicity is encountered, there does exist a possibility of integration and changed identity. The ideal would be to convince cultures to adhere to a Constructivist understanding, incorporating a fixed identity with a flexible identity.

It becomes clear that a new focus in studying religion should also be to search how cultural groups assign meaning to behaviour. This process is contextually determined (cf. Parsons and Geertz). Studying religion should include studying action and meaning and discern the criteria relevant to each ethnic community how to determine meaning. Meaning is determined by values. Studying religion entails studying underlying values in cultures.

The author Jos Vranckx (2016) refers in a recent blog entry on inter-cultural relations in Europe how the French-Iranian sociologist, Farhad Khosrokha, indicates that this process of seeking meaning overlaps with a search for identity. This search for identity is especially prevalent among a new generation of jihadis who come from 'born again'-converts belonging to good educated families. They are seeking identity in a society they perceive as divided and without values, where people are only concerned with entertainment. The values of the two ethnic societies clash. In this encounter, a struggle to find identity ensues.

Studying religion with emphasis on cultural and ethnic interrelatedness requires a distinction between religion as belief and religion as identity marker, or as Ramadan puts, it distinguishes between religion and civilisation (Ramadan 2010:214). This is indeed a difficult task. In a Western understanding determined by Enlightenment thought, such segmentation might be possible. Within other cultural orientations, such a differentiation seems unlikely.

It is clear that when religion functions as identity marker, there are several traditions and myths feeding various claims of racial superiority. Studying religion requires an understanding of the ideological determination of cultural identity. It is necessary to study the myths behind the claims as to racial superiority. Traditions from the past determine social behaviour. A study of the myths and traditions that contribute to racial and religious bias is necessary in order to understand the Other.

From this, it becomes clear that the insights from several disciplines are necessary in order to understand the phenomenon of religion and the interaction between religions.

\section{Making peace with diversity and adversity}

A further implication of the emphasis on studying ethnicity and culture in understanding religion lies on a social level. Can you belong to a culture, not shared in the same race, 
but have the same history? Yes, white Christians participating in the liberation struggle in South Africa marching, protesting side by side to black non-Christian South Africans, are a good example. The question, however, remains whether the two cultural groups are viewed as equals? The answer differs from context to context, depending on the meaning assigned to the behaviour (i.e. participating in the liberation struggle). At times, it may be considered as one culture, as the borders and definition as to what constitutes culture changes.

Is it possible to be a Muslim and belong to Western culture, can one be white and not be labelled a Christian coloniser, or be a black African and not be labelled prone to animism and magic? The answer is, however, 'No!' Cultural and religious identity overlap based on circumstantial conditions. Identity is not only internally constructed. Identity is also externally assigned based on behaviour and the experience of the behaviour by others as well as the meaning assigned to such behaviour. This may lead to cultural and religious bias and generalisations and the creation of stereotypes. One must, however, recognise the circumstantial process that contributed to the formation of identity and perceptions of the other.

The end goal of this research is to contribute to the process of reconciliation between cultural groups in South Africa. Ramadan's position on this matter is to acknowledge diversity (2010:41). One option is to separate culture and religion, ethnicity and religion, and the other is to embrace diversity and complexity. A third possibility is to acknowledge that unity lies in diversity. This entails to maintain religious principles which attach a religious community to the broader community of believers worldwide. The local face of the religious community might look different from the same religious community located in a different cultural setting. Thereby, a discontinuation as well as a continuation is maintained. This is in line with MacKay's suggestion of a Constructivist approach to the relation ethnicity to religion.

The solutions seem to be threefold: separate culture and religion, join culturally but not religiously or join religiously but not culturally. Kilp (2011) indicates how cultural conflict spills over into religious conflict based on the sequence of events. First of all, social, economic and political concerns in a multi-cultural society arise. This leads to feelings of insecurity, chaos and vulnerability which in turn lead to the construction of cultural identities. These constructed identities rely on religious and ideological values, beliefs, myths and narratives framed by morals. This can lead to adversity and conflict.

In this endeavour of trying to reconcile cultures and religions, peace and harmony seem not to lie in creating peace between cultures and religions, but peace lies most probably in accepting the fact that peace and harmony between cultures and religions are most unlikely to happen.

\section{Conclusion}

In this article, I tried to argue that a shift in studying religion is necessary. It has become necessary to emphasise the contributions the studying of cultures and ethnicity has made to the understanding of religion. The arguments used were that cultural migrations necessitate the study of cultures, religion acts as cultural identity marker and religion has relocated to culture. From the discussion, the following elements are clear:

- Studying religion cannot go without studying culture.

- Studying culture cannot go without studying religion.

- Studying inter-religious dialogue cannot go without studying underlying traditions and myths contributing to how the Other is viewed.

The relation between religion and culture seems to be similar to the uneasy relationship between two arguing relatives who cannot deny their connectedness, but wished it otherwise.

\section{Acknowledgements Competing interests}

The author declares that he has no financial or personal relationships which may have inappropriately influenced him in writing this article.

\section{References}

Barth, F., 1969, Ethnic groups and boundaries: The social organization of culture differences, Little \& Brown, Boston, MA

Boyer, P., 2001, Religion explained, Basic Books, New York.

Braun, W., 2000, 'Religion', in W. Braun \& R.T. McCutcheon (eds.), Guide to the study of religion, pp. 3-18, Cassell, London.

Chidester, D., 1996, Savage systems: Colonialism and comparative religion in Southern Africa, University Press of Virginia, Charlottesville, VA.

Cox, J.L., 2010. An introduction to the phenomenology of religion. Continuum Publishing Group, New York.

Figl, J., 2003, 'Wissenschaftsverständnis: Gliederung, Methoden und Teildisziplin', in J. Figl (ed.), Handbuch Religionswissenschaft: Religionen und ihre zentralen Themen, pp. 35-61, Tyrolia Verlag, Innsbruck.

Geertz, C., 1973, The interpretation of cultures: Selected essays, Basic Books, New York

Goodenough, W.H., 1957, 'Cultural anthropology and linguistics', in P.L. Garvin (ed.), Report of the seventh annual round table meeting on linguistics and language study, pp. 167-173, Georgetown University Press, Washington, DC. Monograph study, pp. 167-173, Georgetown University
series on Language and Linguistics No. 9.

Hackett, R.I.J., 2005, 'Anthropology of religion', in J.R. Hinnells (ed.), The Routledge companion to the study of religion, pp. 144-163, Routledge, London.

Kilp, A., 2011, 'Religion in the construction of the cultural "self" and "other"', ENDC Proceedings, 14, 197-222, viewed 7 March 2016, from http://www.ksk.edu.ee/ toimetised

Lincoln, B., 1989, Discourse and the construction of society, Oxford University Press, Oxford.

Lincoln, B., 2000, 'Culture', in W. Braun \& R.T. McCutcheon (eds.), Guide to the study of religion, pp. 409-421, Cassell, London.

MacKay, D.B., 2000, 'Ethnicity', in W. Braun \& R.T. McCutcheon (eds.), Guide to the study of religion, pp. 96-109, Cassell, London.

Minnema, L., 2014, Correlations between types of culture, styles of communication ad forms of interreligious dialogue, HTS Teologiese Studies/Theological Studies 70(1), Art \#2604, 1-7. https://doi.org/10.4102/hts.v70i1.2604

Mulder, D.C., 1985, 'Het vak godsdienstwetenskap', in D.J. Hoens, J.H. Kamstra \& D.C. Mulder (eds.), Inleiding tot de studie van godsdiensten, pp. 35-40, J.H. Kok, Kampen.

Munch, R., \& Smelser, N.J. (ed.), 1992, Theory of culture, University of California Press, Berkeley, CA, viewed 4 March 2016, from http://ark.cdlib.org/ark:/13030/ ft8q2nb667/ 
Parsons, T., 1977, Social systems and the evolution of action theory, The Free Press and Collier MacMillan, New York.

Pattison, G., 2004, Kierkegaard: Religion and the Nineteenth century crisis of culture, Cambridge University Press, Cambridge.

Peacock, J.L., 1981, The third stream, viewed 7 May 2016, from http://www.isca.ox.ac.uk Ramadan, T., 2004, Western Muslims and the future of Islam, Oxford University Press, Oxford.

Ramadan, T., 2010, What I believe, Oxford University Press, Oxford.

Schilderman, H., 2014, 'Defining religion: A humanities perspective', in H. Schilderman (ed.), The concept of religion: Defining and measuring contemporary beliefs and practices, pp. 176-198, Brill, Leiden.
Scott, D. \& Hirschkind, C., 2006, 'Introduction: The Anthropological scepticism of Tala Assad', in D. Scott \& C. Hirschkind (eds.), Powers of the secular modern: Talal Assad and his interlocutors, pp. 1-10, Stanford University Press, Stanford.

Vranckx, J., 2016, Religie niet het probleem maar de oplossing?, viewed 5 April 2016, from www.dewereldmorgen.be/blog/josvranckx/2016/04/04/religie-niet-hetprobleem-maar-de-oplossing

Vroom, H., 1996, Religie als ziel van cultuur: Religieus pluralisme als uitdaging, Meinema, Zoetemeer.

Waggoner, M., 2011, 'Culture and religion', in P.B. Clarke (ed.), The Oxford handbook of sociology of religion, pp. 210-225, Oxford University Press: Oxford.

Woodhead, L., 2011, 'Five concepts of religion', International Review of Sociology 1 121-143. https://doi.org/10.1080/03906701.2011.544192 